\title{
Methoxyluteolin Inhibits Neuropeptide-stimulated Proinflammatory Mediator Release via mTOR Activation from Human Mast Cells $\mathbf{s}$
}

\author{
Arti B. Patel and Theoharis C. Theoharides
}

Molecular Immunopharmacology and Drug Discovery Laboratory, Department of Integrative Physiology and Pathobiology, Tufts University School of Medicine, Boston, Massachusetts (A.B.P. and T.C.T.); Graduate Program in Cell, Molecular and Developmental Biology, Sackler School of Graduate Biomedical Sciences, Tufts University, Boston, Massachusetts (A.B.P.); Departments of Internal Medicine and Psychiatry, Tufts University School of Medicine and Tufts Medical Center, Boston, Massachusetts (T.C.T.)

Received February 7, 2017; accepted March 27, 2017

\begin{abstract}
Mast cells (MCs) are critical for allergic reactions but are also important in inflammatory processes. Stimulation by neuropeptides, such as substance $P(\mathrm{SP})$ and neurotensin (NT), leads to release of preformed molecules stored in numerous $\mathrm{MC}$ secretory granules and newly synthesized proinflammatory mediators, including tumor necrosis factor, C-X-C motif chemokine ligand 8 , and vascular endothelial growth factor. Here, we investigate the role of mammalian target of rapamycin (mTOR) signaling in the stimulation of cultured human LAD2 MCs by NT or SP, as well as the inhibitory effect of the natural flavonoids $3^{\prime}, 4^{\prime}, 5,7$-tetrahydroxyflavone (luteolin) and its novel structural analog $3^{\prime}, 4^{\prime}, 5,7$-tetramethoxyflavone (methoxyluteolin). Stimulation by NT $(10 \mu \mathrm{M})$ or SP $(1 \mu \mathrm{M})$ increases $(P<0.0001)$ gene expression (after 6 hours) and release (after 24 hours) of tumor necrosis factor, $\mathrm{C}-\mathrm{X}-\mathrm{C}$ motif chemokine ligand 8 , and
\end{abstract}

vascular endothelial growth factor. This occurs via activation of both mTOR complexes, as denoted by the increased phosphorylated $(p)$ protein levels $(P<0.0001)$ of the downstream mTORC1 substrate pp70S6KThr389 and mTORC2 component pmTORSer2448. Pretreatment of human MCs using the mTORC1 inhibitor rapamycin, the mTORC1/mTORC2 inhibitor Torin1, or the two flavonoids decreases both gene expression and release $(P<0.0001)$ of all three mediators. Methoxyluteolin is a more potent human MC inhibitor than luteolin or Torin1, implicating other MC protein targets in addition to the mTOR complex. These findings indicate that mTOR is partially involved in the neuropeptide stimulation of MCs, but the novel flavonoid methoxyluteolin inhibits the response entirely, suggesting that it may be developed for treatment of allergic and inflammatory diseases.

\section{Introduction}

Mast cells (MCs) are unique immune cells that derive from hematopoietic precursors and mature in vascularized tissues (Rodewald et al., 1996; Kitamura and Ito, 2005; Schmetzer et al., 2016). In addition to stimulation by the high-affinity IgE receptor (FceRI) (Rivera et al., 2008), MCs are also activated by bacterial endotoxins such as lipopolysaccharides via the Toll-like receptors (Palaska et al., 2016) and neuropeptides such as neurotensin (NT) (Lazarus et al.,

This research was supported in part by a grant from the Jane Botsford Johnson Foundation (to T.C.T.) and a predoctoral fellowship from the Nancy Lurie Marks Family Foundation (to A.B.P.). The following U.S. patents were recently awarded to the senior and corresponding author (T.C.T.), who has signed an agreement with Tufts University: US 9,050,275 (Methods of Screening for and Treating Autism Spectrum Disorders and Compositions for Same) and US 9,176,146 (Methods of Treating Autism Spectrum Disorders and Compositions for Same).

https://doi.org/10.1124/jpet.117.240564.

S This article has supplemental material available at jpet.aspetjournals.org.
1977; Kulka et al., 2008) and substance P (SP) (Church et al., 1991; Theoharides et al., 2010), Stimulated MCs release prestored molecules, including histamine, heparin, and tryptase, as well as de novo synthesized proinflammatory mediators such as tumor necrosis factor (TNF), C-X-C motif chemokine ligand 8 (CXCL8), and vascular endothelial growth factor (VEGF) (Theoharides et al., 2012a). As a result, MCs are involved not only in allergies (Galli and Tsai, 2012) but also in immunity (Galli et al., 2008), MC disorders (including mastocytosis) (Theoharides et al., 2015), and inflammatory diseases (Theoharides and Cochrane, 2004; Theoharides et al., 2012).

The neuropeptides SP (Chang and Leeman, 1970) and NT (Carraway and Leeman, 1973), initially characterized by Leeman and colleagues, are implicated in inflammatory processes (Mashaghi et al., 2016). Increased levels of SP have been associated with inflammatory diseases (O'Connor et al., 2004) and the crosstalk between the endocrinology system and the skin (Caraffa et al., 2016), leading to disorders such as

ABBREVIATIONS: ASD, autism spectrum disorder; CXCL8, C-X-C motif chemokine ligand 8; DMSO, dimethylsulfoxide; ELISA, enzyme-linked immunosorbent assay; FceRI, high-affinity lgE receptor; LY294002, 2-morpholin-4-yl-8-phenylchromen-4-one; MC, mast cell; mTOR, mammalian target of rapamycin; NF- $\kappa$ B, nuclear factor- $\kappa \mathrm{B}$; NT, neurotensin; p, phosphorylated; PI3K, phosphatidylinositol 3-kinase; S6K, S6 kinase; SP, substance P; TNF, tumor necrosis factor; VEGF, vascular endothelial growth factor. 
psoriasis (Remröd et al., 2007). Circulating levels of NT have been reported in patients with psoriasis and atopic dermatitis (Vasiadi et al., 2012). MC-derived CXCL8 enhances recruitment of immune cells to the site of inflammation (Salamon et al., 2005), whereas VEGF can increase vascular permeability (Donelan et al., 2006). Although the allergic stimulation of MCs is fairly well characterized (Rivera et al., 2008), less is known about the stimulation of MCs by neuropeptides. A receptor (Mrgprx2) was recently identified as being critical in pseudo-allergies, some of which are due to MC activation by cationic drugs and molecules (McNeil et al., 2015), but NT and SP were not studied.

The phosphatidylinositol 3-kinase (PI3K)-dependent mammalian target of rapamycin (mTOR) kinase pathway (Dibble and Cantley, 2015) has been implicated in the regulation of normal MC homeostasis and function (Kim et al., 2008a), including FceRI-mediated allergic responses (Smrz et al., 2011), but has not been studied in neuropeptide-stimulated MCs. The mTOR catalytic subunits exist in two complexes: 1) mTORC1, involved in protein translational control by phosphorylation of ribosomal S6 kinases ( $66 \mathrm{Ks}$ ) and the eukaryotic initiation factor 4E-binding proteins (4EBP1); and 2) mTORC2, implicated in cytoskeleton reorganization (Laplante and Sabatini, 2012). It was previously shown that mTORC1 is involved in the allergic stimulation of MCs (Kim et al., $2008 \mathrm{~b}$ ) and is constitutively activated in cultured human LAD2 MCs (Kim et al., 2008a). Other studies revealed that mTORC2 mediates MC chemotaxis (Kuehn et al., 2011) and proliferation of neoplastic human MCs (Smrz et al., 2011). Downregulation of the upstream mTOR inhibitory protein phosphatase and tensin homolog leads to increased MC activation (Furumoto et al., 2006) and a mastocytosis-like state (Furumoto et al., 2011).

To date, there are still no clinically effective MC inhibitors (Theoharides et al., 2012a; Finn and Walsh, 2013). Disodium cromoglycate (cromolyn) is known as an "MC stabilizer" because it inhibits rodent peritoneal MC histamine release (Theoharides et al., 1980), but it does not effectively inhibit either murine (Oka et al., 2012) or human (Weng et al., 2012) MCs. Although the local application of an experimental cromolyn ointment reduced histamine-induced pruritus in the human skin, it apparently did so via modulation of sensory nerves and not by inhibiting MCs (Vieira Dos Santos et al., 2010). Moreover, inhibitors of the tyrosine kinase c-kit receptor that reduce MC proliferation (Heinrich et al., 2000) do not inhibit MC activation (Gotlib et al., 2016). Tacrolimus was developed as an mTOR inhibitor for skin inflammatory diseases (Michel et al., 1996) but has been associated with allergic responses (Beck, 2005). Hence, there is an urgent need for the development of effective inhibitors of human MCs. The natural flavonoid 3,5,7,3',4'-pentahydroxyflavone (quercetin) was shown to be more potent than cromolyn in inhibiting photosensitivity in humans (Weng et al., 2012). Quercetin (Mlcek et al., 2016) and 3',4',5,7-tetrahydroxyflavone (luteolin) are natural antioxidant and anti-inflammatory flavonoids (Middleton et al., 2000), which also inhibit MC histamine, TNF, and VEGF (Kempuraj et al., 2005) as well as release of leukotrienes and prostaglandin D2 (Kimata et al., 2000). We recently showed that its structural analog, 3',4',5,7tetramethoxyflavone (methoxyluteolin), is a more potent MC inhibitor (Weng et al., 2015) and is also more metabolically stable (Walle, 2007).
In this study, we report that mTOR activation is involved in the stimulation of human MCs by the neuropeptides NT and $\mathrm{SP}$, and this mechanism is inhibited by the flavonoids luteolin and methoxyluteolin.

\section{Materials and Methods}

Materials. SP (S6883) and NT (N6383) were obtained from Sigma-Aldrich (St. Louis, MO). PI3K inhibitor LY294002 [2morpholin-4-yl-8-phenylchromen-4-one] (Cell Signaling Technology, Danvers, MA) and mTOR inhibitors (rapamycin and Torin1 Tocris Biosciences, Bristol, UK) were purchased. The flavonoids luteolin and methoxyluteolin were obtained from Pharma Science Nutrients (Clearwater, FL). RNeasy mini kits (Qiagen, Valencia, CA) and iScript cDNA synthesis kits (Bio-Rad, Hercules, CA) were purchased. TaqMan gene expression primers/assays for TNF (Hs99999043_m1), CXCL8 (Hs00174103_m1), VEGFA (Hs00900055_m1), and the glyceraldehyde 3-phosphate dehydrogenase endogenous control (4310884E) were purchased from Applied Biosystems (Foster City, CA). Enzyme-linked immunosorbent assay (ELISA) kits for TNF (DY210), CXCL8 (DY208), and VEGF (DY293B) were purchased from R\&D Biosystems (Minneapolis, MN). The following rabbit monoclonal antibodies were purchased from Cell Signaling Technology: mTOR (7C10), pmTORSer2448 (D9C2), pmTORSer2481, and mTORC1 substrates p70S6K (49D7), pp70SK Thr389 (108D2), 4EBP1 (53H11) and p4EBP1Thr37/46 (236B4), as well as the loading control $\beta$-actin (D6A8). PathScan Sandwich ELISA kits for total and phosphorylated mTOR and its substrates were also purchased from Cell Signaling Technology.

Human MC Culture. LAD2 MCs (kindly supplied by Dr. A. S. Kirshenbaum, National Institutes of Health, Bethesda, MD), derived from human MC leukemia (Kirshenbaum et al., 2003), were cultured in StemPro-34 SFM medium (Invitrogen, Carlsbad, CA) supplemented with $100 \mathrm{U} / \mathrm{ml}$ penicillin/streptomycin and $100 \mathrm{ng} / \mathrm{ml}$ recombinant human stem cell factor (kindly supplied by Swedish Orphan Biovitrum AB, Stockholm, Sweden). These cells have been used numerous times in our laboratory and are shown to behave like primary human umbilical cord bloodderived MCs. Cell viability was determined by trypan blue $(0.4 \%)$ exclusion.

LAD2 MC Treatments. LAD2 MCs were stimulated with NT (1-10 $\mu \mathrm{M}$; Sigma-Aldrich) or SP (1 $\mu \mathrm{M}$; Sigma-Aldrich) and/or preincubated with dimethylsulfoxide (DMSO) or the following: 1) PI3K inhibitors (1-10 $\mu \mathrm{M}$ LY294002, 2 hours; Cell Signaling Technology), 2) mTOR inhibitors (0.005-0.2 $\mu \mathrm{M}$ rapamycin or $0.005-0.2 \mu \mathrm{M}$ Torin1; Tocris Biosciences), and 3) flavonoids (1-50 $\mu \mathrm{M}$ luteolin or methoxyluteolin, 2, 12, or 24 hours; Pharma Science Nutrients). All inhibitors were dissolved in water or DMSO with a final concentration of $<0.1 \%$.

Proinflammatory Mediator Release by ELISA. Mediator release in cell-conditioned culture medium/supernatant fluid was determined by using commercially available ELISA kits (R\&D Systems) per the manufacturer's instructions. LAD2 MCs $(0.5 \times$ $10^{6}$ cells/well) were seeded in 96 -well flat-bottom Falcon culture plates (Becton Dickinson, Franklin Lakes, NJ) prior to pretreatment with inhibitors/flavonoids (for 30 minutes) and NT or SP stimulation for 24 hours. MC supernatant fluids were collected and TNF, CXCL8, and VEGF mediator release was measured. For all experiments, the control cells were treated with an equal volume of culture medium or DMSO, and the minimum detectable level for all by ELISAs was $5 \mathrm{pg} / \mathrm{ml}$.

MC Degranulation. LAD2 MCs were stimulated with the neuropeptides NT (10 $\mu \mathrm{M}$; Sigma-Aldrich) or SP (1 $\mu \mathrm{M}$; Sigma-Aldrich) for 30 minutes. $\beta$-hexosaminidase release was assayed using a fluorometric method as previously reported (Weng et al., 2015). To determine $\beta$-hexosaminidase activity, both the supernatant fluid and cell lysates $\left(0.5 \times 10^{5}\right.$ cells per tube, lysed with $1 \%$ Triton X-100 to 
measure residual cell-associated $\beta$-hexosaminidase) were incubated with substrate solution ( $p$-nitrophenyl- $N$-acetyl- $\beta$-D-glucosaminide; Sigma-Aldrich) in $0.1 \mathrm{M} \mathrm{NaOH} / 0.2 \mathrm{M}$ glycine. Absorbance was read at $405 \mathrm{~nm}$ in a plate reader (Laboratory Systems Multiskan RC; Thermo Fisher Scientific, Rockford, IL), and the results were expressed as the percentage of $\beta$-hexosaminidase released over the total.

Proinflammatory Mediator Gene Expression by Quantitative Reverse Transcription Polymerase Chain Reaction. Total RNA from LAD2 MCs was isolated using the RNeasy Mini Kit (Qiagen) according to the manufacturer's instructions. Reverse transcription was performed with $300 \mathrm{ng}$ total RNA using the iScript cDNA synthesis kit (Bio-Rad). Gene expression of TNF, CXCL8, and VEGF mediators in LAD2 MCs $\left(1 \times 10^{6}\right.$ cells per six-well plate), those preincubated with inhibitors/flavonoids, and/or those stimulated with NT or SP was measured after 6 hours. Quantitative real-time polymerase chain reaction was performed using TaqMan gene expression assays to assess gene expression of the mediators using validated oligonucleotide primers (Applied Biosystems, Carlsbad, CA). Samples were run for 45 cycles using the Applied Biosystems 7300 RealTime PCR System. Relative mRNA abundance was determined from standard curves run for each experiment. Gene expression was normalized to the glyceraldehyde 3-phosphate dehydrogenase endogenous control.

Assessing mTOR Activation by Western Blot and ELISA. The activation of mTOR was assessed by phosphorylation of downstream mTORC1 and mTORC2 substrates by Western blot analysis and using PathScan total and phospho-ELISA kits Cell Signaling Technology LAD2 MCs $\left(1 \times 10^{6}\right.$ cells per flask $)$ were pretreated with inhibitors or flavonoids for the indicated doses and times and then stimulated with NT or SP for 0-60 minutes. Thereafter, cells were pelleted and lysates were harvested in radioimmunoprecipitation assay buffer (Sigma-Aldrich) containing Halt Protease and Phosphatase Inhibitor Cocktail (Thermo Fisher Scientific). Total protein concentrations were determined by the bicinchoninic acid assay (Thermo Fisher Scientific) using bovine serum albumin protein as standards. The total proteins ( 20 or $40 \mu \mathrm{g}$ ) were separated using 4\%20\% Mini-PROTEAN TGX Precast Gels (Bio-Rad) under SDS denaturing conditions and were electrotransferred onto polyvinylidene fluoride membranes (EMD Millipore, Billerica, MA). Blocking was carried out with $5 \%(\mathrm{w} / \mathrm{v})$ bovine serum albumin in Tris-buffered saline containing $0.1 \%$ Tween 20 . The Western Blots were probed with the following primary antibodies: mTOR (7C10), pmTOR (Ser2448), and mTORC1 substrates p70S6K, pp70SK (Thr389), 4EBP1, and p4EBP1 (Thr-37/46), whereas $\beta$-actin served as the loading control (Cell Signaling Technology). All proteins were visualized with horseradish peroxidase-conjugated secondary antibodies and then by SuperSignal West Pico enhanced chemiluminescence (Thermo Fisher Scientific). To quantitate changes in protein phosphorylation, the films were scanned and densitometric analysis was carried out using ImageJ software (https://imagej.nih.gov/ij/; National Institutes of Health, Bethesda, MD). In parallel experiments, Cell Signaling Technology's PathScan mTOR, pmTOR (Ser2448), p70S6K, pp70S6K (Thr389), 4EBP1, and p4EBP1 sandwich ELISA kits were used to measure the levels of total and phosphorylated mTORC1 substrates in MCs after the treatments described.

Statistical Analysis. All conditions were performed in triplicate and all experiments were repeated at least three times. Results from cultured cells are presented as means \pm S.D. Comparisons were made between control and stimulated cells using the unpaired two-tailed $t$ test. In addition, multiple comparisons were made between: 1 ) stimulated cells without inhibitors/flavonoids (DMSO or buffer control) and those with inhibitors/flavonoids using one-way analysis of variance, followed by post hoc analysis by the Dunnett multiplecomparisons test; and 2) all of the conditions with inhibitor/flavonoid among themselves using one-way analysis of variance, followed by post hoc analysis by the Tukey multiple-comparisons test. All statistical analyses were performed using GraphPad Prism software (version 5.0; GraphPad Software, San Diego, CA). Significance was denoted by $P<0.05, P<0.001$, and $P<0.0001$. Representative images for Western blots were scanned and analyzed using ImageJ software.

\section{Results}

Neuropeptide-Stimulated Human MC Proinflammatory Mediator Release Is Inhibited by PI3K or mTOR Inhibitors. Initially, we investigated the optimal concentrations of NT or SP $(1-10 \mu \mathrm{M})$ that stimulated de novo proinflammatory mediator release from cultured human LAD2 MCs. Stimulation by NT $(10 \mu \mathrm{M})$ and SP $(1 \mu \mathrm{M})$ significantly increased the release of TNF, CXCL8, and VEGF from human LAD2 MCs after 24 hours. Using these optimal concentrations, we next evaluated the involvement of mTOR signaling by employing pharmacological inhibitors of mTOR, which included rapamycin (a bacterial macrolide and more selective mTORC1 inhibitor), Torin1 (a more potent ATPcompetitive dual inhibitor of mTOR), and LY294002 (an upstream PI3K inhibitor).

Pretreatment of LAD2 MCs (24 hours) with mTOR signaling inhibitors rapamycin and Torin1 dose-dependently (0.05-0.2 $\mu \mathrm{M}$ ) decreased SP-stimulated TNF (Fig. 1A) and CXCL8 (Fig. 1B) release from human MCs. At the optimal inhibitory concentration of $0.2 \mu \mathrm{M}$, Torin 1 significantly decreased $(P<0.001)$ proinflammatory mediator release from SP-stimulated LAD2 MCs compared with rapamycin, which is more selective for mTORC1 inhibition. Pretreatment with PI3K inhibitor LY294002 (1-10 $\mu \mathrm{M}, 2$ hours) decreased $(P<$ 0.0001) TNF and CXCL8 release, with an optimal inhibitory concentration of $10 \mu \mathrm{M}$ (Fig. 1C).

Neuropeptide-Stimulated Human MC Degranulation Is Decreased by the PI3K Inhibitor and the Flavonoids Luteolin and Methoxyluteolin, But Not mTOR Inhibitors. Unlike their effect on de novo synthesized mediator release, pretreatment of LAD2 MCs with the mTOR inhibitors rapamycin or Torin 1 ( $0.2 \mu \mathrm{M}, 24$ hours), followed by stimulation with either NT (Supplemental Fig. 1A) or SP (Supplemental Fig. 1B) for 30 minutes had no effect on $\beta$-hexosaminidase release from LAD2 MCs. The upstream PI3K inhibitor LY294002 (10 $\mu \mathrm{M}, 2$ hours) or the flavonoids luteolin and methoxyluteolin also had no effect on $\beta$-hexosaminidase release from LAD2 MCs at $10 \mu \mathrm{M}$; however, all three compounds significantly decreased $(P<0.001)$ $\beta$-hexosaminidase release at $50 \mu \mathrm{M}$ when used for 24 hours (Supplemental Fig. 1).

Neuropeptide-Stimulated Human MC Proinflammatory Mediator Release Is Inhibited by the Flavonoids Luteolin and Methoxyluteolin. LAD2 MCs were first pretreated with luteolin and methoxyluteolin at various doses (1-50 $\mu \mathrm{M}, 2$ hours) and then stimulated by NT $(10 \mu \mathrm{M})$ for 24 hours to identify the most effective concentration inhibiting release of proinflammatory mediators. Methoxyluteolin decreased the release of all mediators at equimolar flavonoid concentrations more potently than luteolin $(P<0.001)$ (Supplemental Fig. 2). We further compared the effects of the PI3K/mTOR inhibitors to the flavonoids luteolin and methoxyluteolin on LAD2 MC mediator release after neuropeptide stimulation for 24 hours. LAD2 MCs were pretreated with inhibitors of mTOR (rapamycin or Torin 1, $0.2 \mu \mathrm{M}$, 

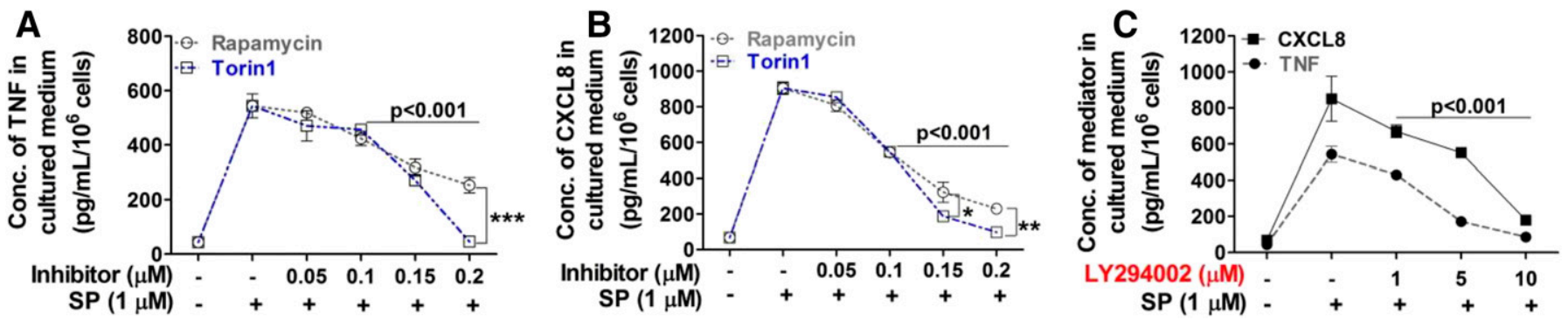

Fig. 1. Inhibitors of mTOR signaling dose-dependently decrease SP-stimulated proinflammatory mediator release from human MCs. (A and B) LAD2 MCs $\left(0.5 \times 10^{6}\right.$ cells $)$ were pretreated with the mTOR inhibitor rapamycin $(0.05-0.2 \mu \mathrm{M}, 24$ hours $)$ or the ATP-competitive mTOR inhibitor Torin 1 (0.05-0.2 $\mu \mathrm{M}, 24$ hours) prior to stimulation with SP (1 $\mu \mathrm{M})$ for 24 hours to measure release of TNF (A) and CXCL8 (B) by ELISA. (C) LAD2 MCs $\left(0.5 \times 10^{6}\right.$ cells) were also pretreated with the upstream PI3K inhibitor LY294002 (1-10 $\mu \mathrm{M}, 2$ hours) prior to stimulation with SP (1 $\left.\mu \mathrm{M}\right)$ for 24 hours to measure release of TNF and CXCL8 mediators. All inhibitors were dissolved in water or DMSO with a final concentration of $<0.1 \%$. All conditions were performed in triplicate for each data set and were repeated three times. Results are presented as means \pm S.D. Significance of comparisons was assessed for stimulated cells without any inhibitor (control) and for those with an inhibitor/flavonoid, as denoted by the horizontal lines that indicate significance at $P<0.001$ for each comparison made. All inhibitor/flavonoid treatments were also compared among themselves, and the vertical brackets indicate the corresponding levels of significance when present $(* P<0.05 ; * * P<0.001 ; * * P<0.0001)$.

24 hours) or PI3K (10 $\mu \mathrm{M}, 2$ hours) and the flavonoids luteolin or methoxyluteolin $(50 \mu \mathrm{M}, 2$ hours $)$ and then stimulated by NT $(10 \mu \mathrm{M})$ or SP $(1 \mu \mathrm{M})$ for 24 hours. The release of TNF, CXCL8, and VEGF significantly decreased in the presence of the flavonoids $(P<0.0001)$ after stimulation by either NT (Fig. 2, A-C) or SP (Fig. 2, D-F).
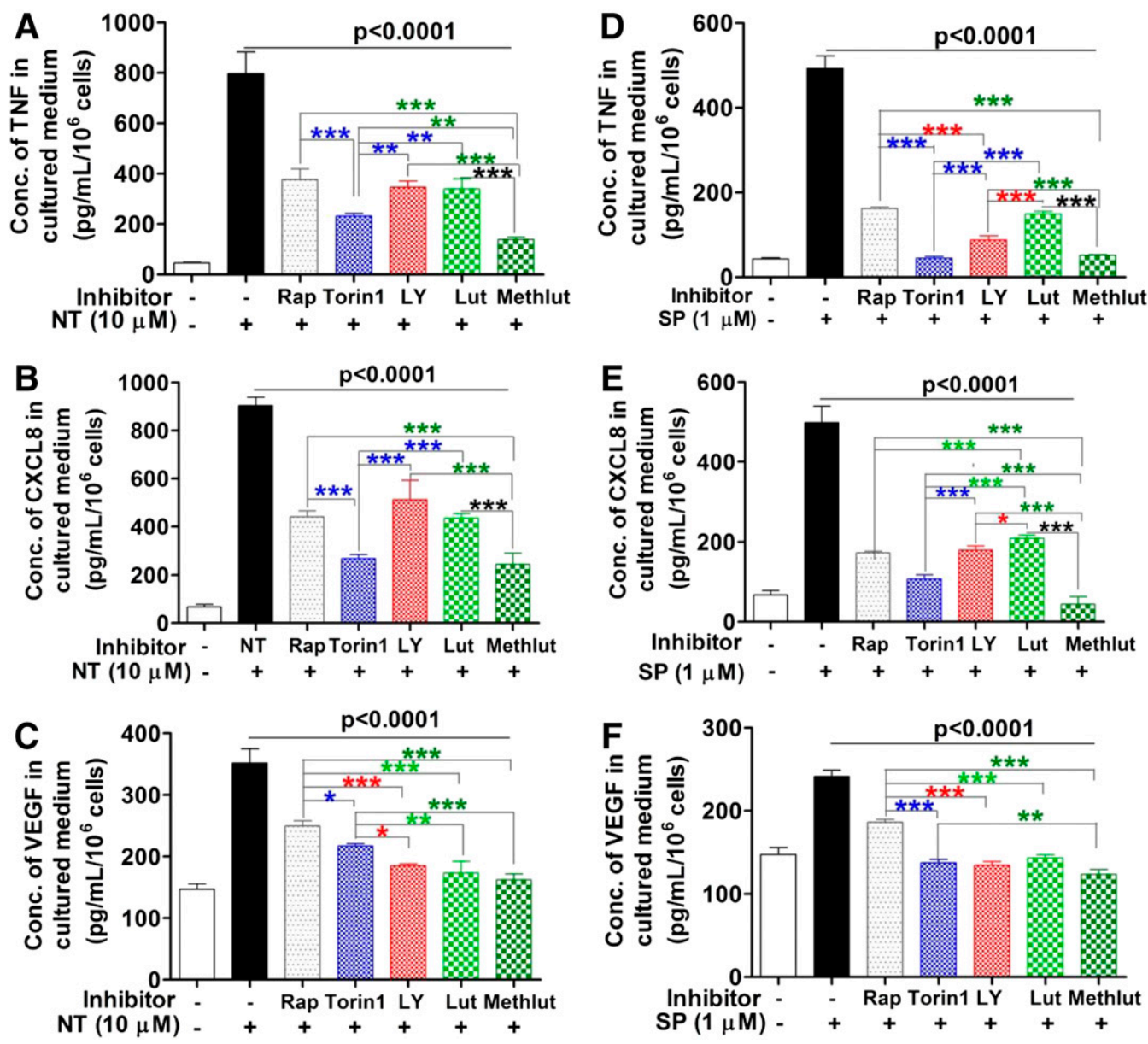

Fig. 2. Human MC proinflammatory mediator release in response to NT or SP is attenuated by PI3K/mTOR inhibitors and the flavonoids luteolin and methoxyluteolin. (A-F) LAD2 MCs $\left(0.5 \times 10^{6}\right.$ cells) were pretreated with the mTOR inhibitors rapamycin (Rap) and Torin1 (0.2 $\mu \mathrm{M}, 24$ hours), the upstream PI3K inhibitor LY294002 (LY; $10 \mu \mathrm{M}, 2$ hours), or the natural flavonoids luteolin (Lut) and methoxyluteolin (Methlut; $50 \mu \mathrm{M}, 30$ minutes) and then stimulated with NT $(10 \mu \mathrm{M})(\mathrm{A}-\mathrm{C})$ or the positive control trigger SP $(1 \mu \mathrm{M})(\mathrm{D}-\mathrm{F})$ for 24 hours to measure release of TNF, CXCL8, and VEGF mediators by specific ELISAs. All conditions were performed in triplicate for each data set and were repeated three times, with results presented as means \pm S.D. Significance of comparisons was assessed for stimulated cells without any inhibitor (control) and for those with an inhibitor/flavonoid, as denoted by the horizontal lines that indicate significance at $P<0.0001$ for each comparison made. All inhibitor/flavonoid treatments were also compared among themselves, and the horizontal brackets indicate the corresponding levels of significance when present $\left({ }^{*} P<0.05 ; * * P<0.001 ; * * * P<0.0001\right)$. 
Neuropeptide-Stimulated Proinflammatory Mediator Gene Expression in Human MCs Is Decreased by the PI3K or mTOR Inhibitors and by Luteolin and Methoxyluteolin. We further investigated whether mTOR signaling is involved in the gene transcription of proinflammatory mediators in human MCs stimulated by either NT or SP. LAD2 MCs were pretreated with the mTOR inhibitors rapamycin and Torin $1(0.2 \mu \mathrm{M}, 24$ hours $)$ and the upstream PI3K inhibitor LY294002 (10 $\mu \mathrm{M}, 2$ hours) prior to stimulation with NT $(10 \mu \mathrm{M})$ or SP $(1 \mu \mathrm{M})$ for 6 hours. Stimulation of LAD2 MCs by either NT (Fig. 3, A-C) or SP (Fig. 3, D-F) significantly increased $(P<0.001)$ gene expression of TNF, CXCL8, and VEGF, which decreased $(P<0.0001)$ after treatment with the PI3K/mTOR inhibitors (Fig. 3).

Pretreatment with either luteolin or methoxyluteolin also significantly decreased $(P<0.0001)$ gene expression of TNF, CXCL8, and VEGF in response to NT or SP (Fig. 3). Methoxyluteolin $(50 \mu \mathrm{M})$ was more potent $(P<0.05)$ than luteolin or the PI3K inhibitor LY294002 $(P<0.001)$ for inhibition of TNF and CXCL8, but not for VEGF gene expression (Fig. 3 , $\mathrm{C}$ and $\mathrm{F}$ ).

Neuropeptide Stimulation of Human MCs Activates Signaling via mTOR That Is Inhibited by Methoxyluteolin. To investigate the specific mTOR complex activated in response to NT or SP stimulation, Western blot analysis was performed to detect the total and phosphorylated levels of mTOR (pmTORSer2448, an indicator of signaling via mTORC2) and the mTORC1 substrates p70S6K (pp70S6KThr389) and 4EBP1 (p4EBP1Thr37/46) proteins (Fig. 4A). Densitometric analysis revealed that stimulation of LAD2 MCs with either NT $(10 \mu \mathrm{M})$ or SP $(1 \mu \mathrm{M})$ increased $(P<0.0001)$ the levels of pmTORSer2448 (Fig. 4, A and D) and the downstream mTORC1 substrate, pp70S6KThr389 (Fig. 4, B and E) after 20 minutes, compared with control cells. To note, stimulation with NT or SP had no effect on the levels of p4EBP1Thr37/46, as shown by Western blotting (Fig. 4, C and F).
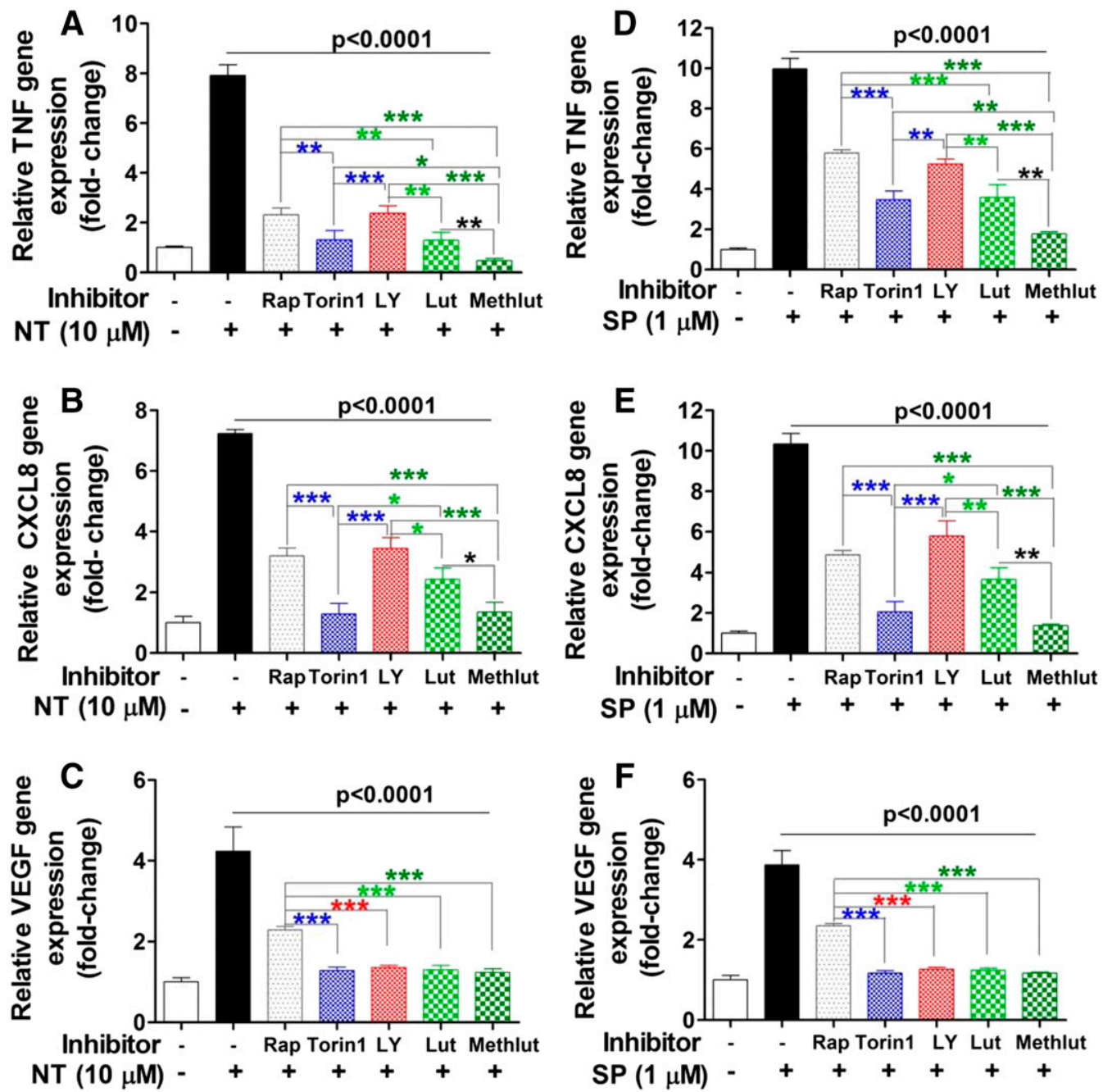

Fig. 3. Human LAD2 MC proinflammatory mediator gene expression in response to NT or SP is inhibited by the PI3K/mTOR inhibitors luteolin and methoxyluteolin. (A-F) LAD2 MCs $\left(1 \times 10^{6}\right.$ cells) were pretreated with the mTOR inhibitors rapamycin (Rap) and Torin 1 ( $0.2 \mu \mathrm{M}, 2$ or 24 hours), the upstream PI3K inhibitor LY294002 (LY; $10 \mu \mathrm{M}, 2$ hours), or the natural flavonoids luteolin (Lut) and methoxyluteolin (Methlut; $50 \mu \mathrm{M}$, 30 minutes) prior to stimulation with NT $(10 \mu \mathrm{M})(\mathrm{A}-\mathrm{C})$ or the positive control trigger SP $(1 \mu \mathrm{M})(\mathrm{D}-\mathrm{F})$ for 6 hours to measure gene expression of TNF, CXCL8, and VEGF by quantitative real-time polymerase chain reaction. All inhibitors were dissolved in water or DMSO with a final concentration of $<0.1 \%$. All conditions were performed in triplicate for each data set and were repeated three times, with results presented as means \pm S.D. Significance of comparisons was assessed for stimulated cells without any inhibitor (control) and for those with inhibitor/flavonoid, as denoted by the horizontal lines that indicate significance at $P<0.0001$ for each comparison made. All inhibitor/flavonoid treatments were also compared among themselves, and the horizontal brackets indicate the corresponding levels of significance when present $(* P<0.05 ; * * P<0.001 ; * * * P<0.0001)$. 
A
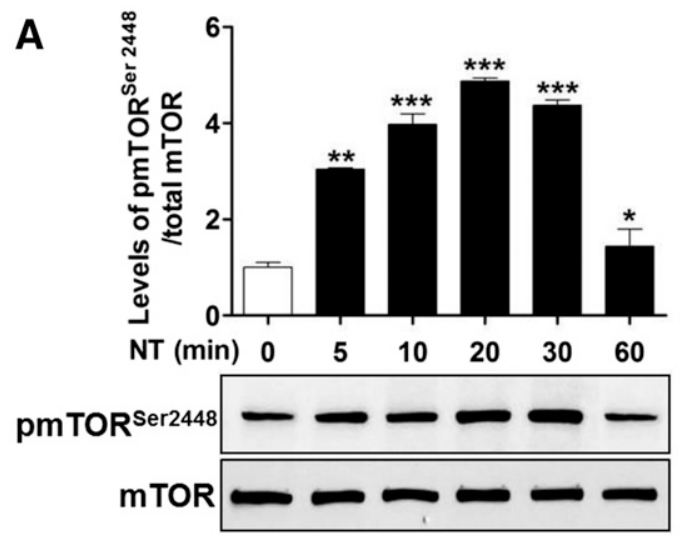

B
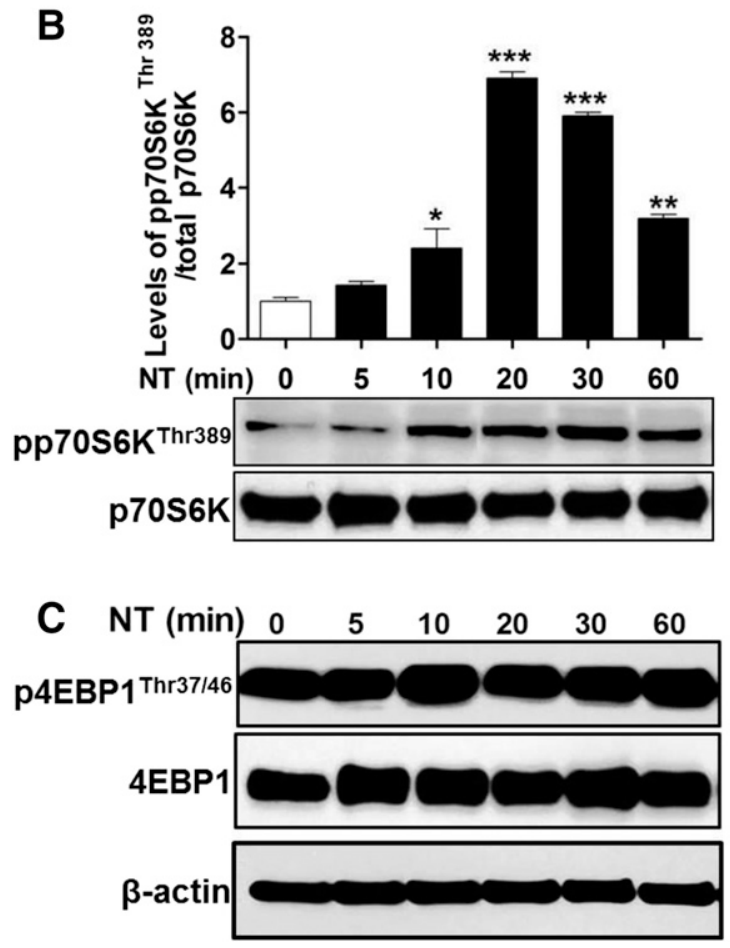

D
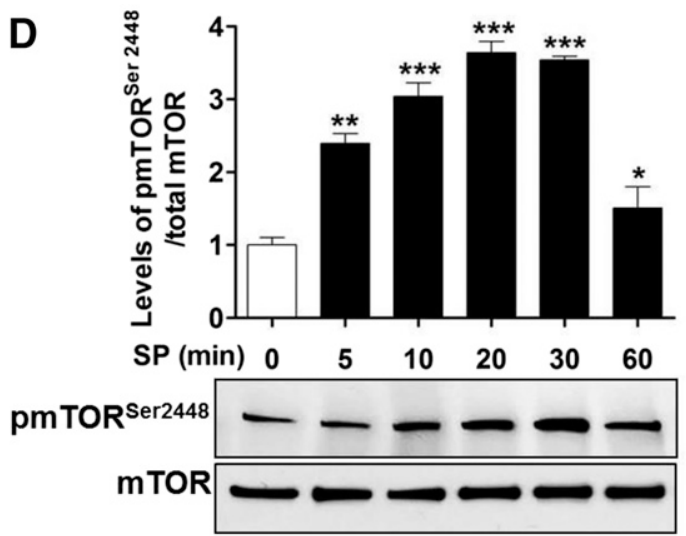

E

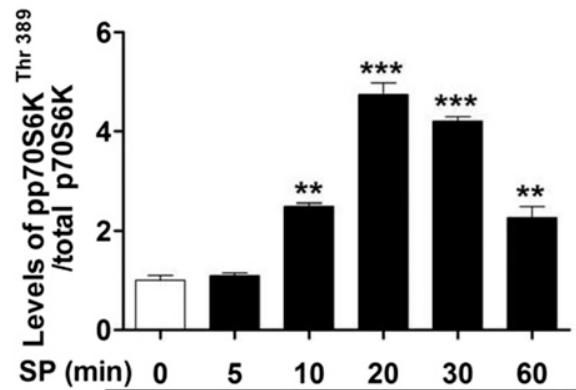

pp70S6K ${ }^{\text {Thr389 }}=-\infty \omega$

p70s6K

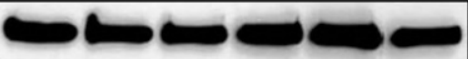

$\mathbf{F}$

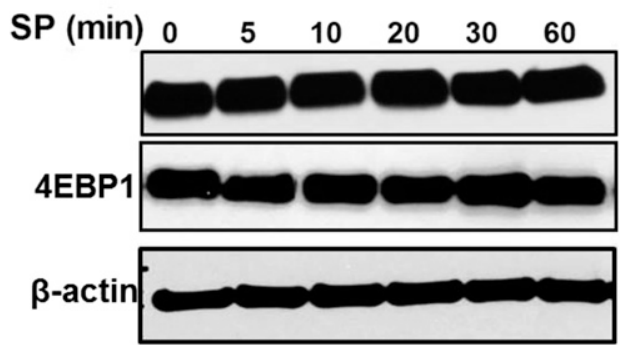

Fig. 4. NT and SP stimulate mTOR activation in human LAD2 MCs. (A-F) LAD2 MCs $\left(1 \times 10^{6}\right.$ cells) were stimulated with NT (10 $\mu$ M) (A-C) or the positive control trigger SP $(1 \mu \mathrm{M})(\mathrm{D}-\mathrm{F})$ for $0-60$ minutes to probe for the total and phosphorylated levels of mTOR and substrates $\mathrm{p} 70 \mathrm{~S} 6 \mathrm{~K}$ and $4 \mathrm{EBP} 1$ by Western blot analysis. Peak mTOR activation was denoted at 20 minutes for pmTORSer2448 and pp70S6KThr389 proteins, whereas the levels of p4EBP1Thr37/46 protein remained unchanged. Results were quantified using densitometric analyses for pmTORSer2448 to mTOR levels (B and D) and pp70S6KThr389 to p70S6K levels (B and E) in response to NT $(10 \mu \mathrm{M})$ or SP $(1 \mu \mathrm{M})$. All conditions were performed in triplicate for each data set and were repeated three times, with results presented as means \pm S.D. Significance of comparisons was assessed for unstimulated cells without NT or SP treatment and for those stimulated by the neuropeptides $\left({ }^{*} P<0.05 ; * * P<0.001 ;{ }^{* * *} P<0.0001\right)$.

Since PI3K upstream of mTOR signaling has been implicated in the activation of MCs (Kim et al., 2008b), we further evaluated the inhibitory effects of luteolin and methoxyluteolin on mTOR in NT- or SP-stimulated LAD2 MCs. LAD2 MCs were preincubated with rapamycin or Torin 1 ( $0.2 \mu \mathrm{M}, 24$ hours), LY294002 (10 $\mu \mathrm{M}, 2$ hours), or luteolin and methoxyluteolin (50 $\mu \mathrm{M}, 2$ hours) prior to NT $(10 \mu \mathrm{M})($ Fig. 5 , A-C) or SP $(1 \mu \mathrm{M})$ (Fig. $5, \mathrm{D}-\mathrm{F})$ stimulation for 20 minutes. The PI3K/mTOR and flavonoid inhibitors significantly decreased levels of pmTORSer2448 and pp70S6KThr389, compared with those of neuropeptidestimulated LAD2 MCs.

To further quantify the levels of phosphorylated mTOR and its substrates, phospho-ELISAs were also performed on LAD2 MCs pretreated with the PI3K/mTOR inhibitors or luteolin and methoxyluteolin prior to stimulation with NT or SP. Levels of pmTOR Ser2448 (Fig. 5, A and D) and pp70S6K Thr389 proteins (Fig. 5, B and E) increased in response to stimulation with NT or SP but significantly decreased $(P<0.001)$ after pretreatment with all of the inhibitors. To note, methoxyluteolin showed a greater reduction in pmTORSer2448 and pp70S6KThr389 levels, compared with the PI3K inhibitor LY294002 $(P<0.0001)$ or luteolin at equimolar flavonoid concentrations $(P<0.001)$ (Fig. 5).

\section{Discussion}

A novel finding reported here is the involvement of mTOR signaling in the synthesis and release of TNF, CXCL8, and 

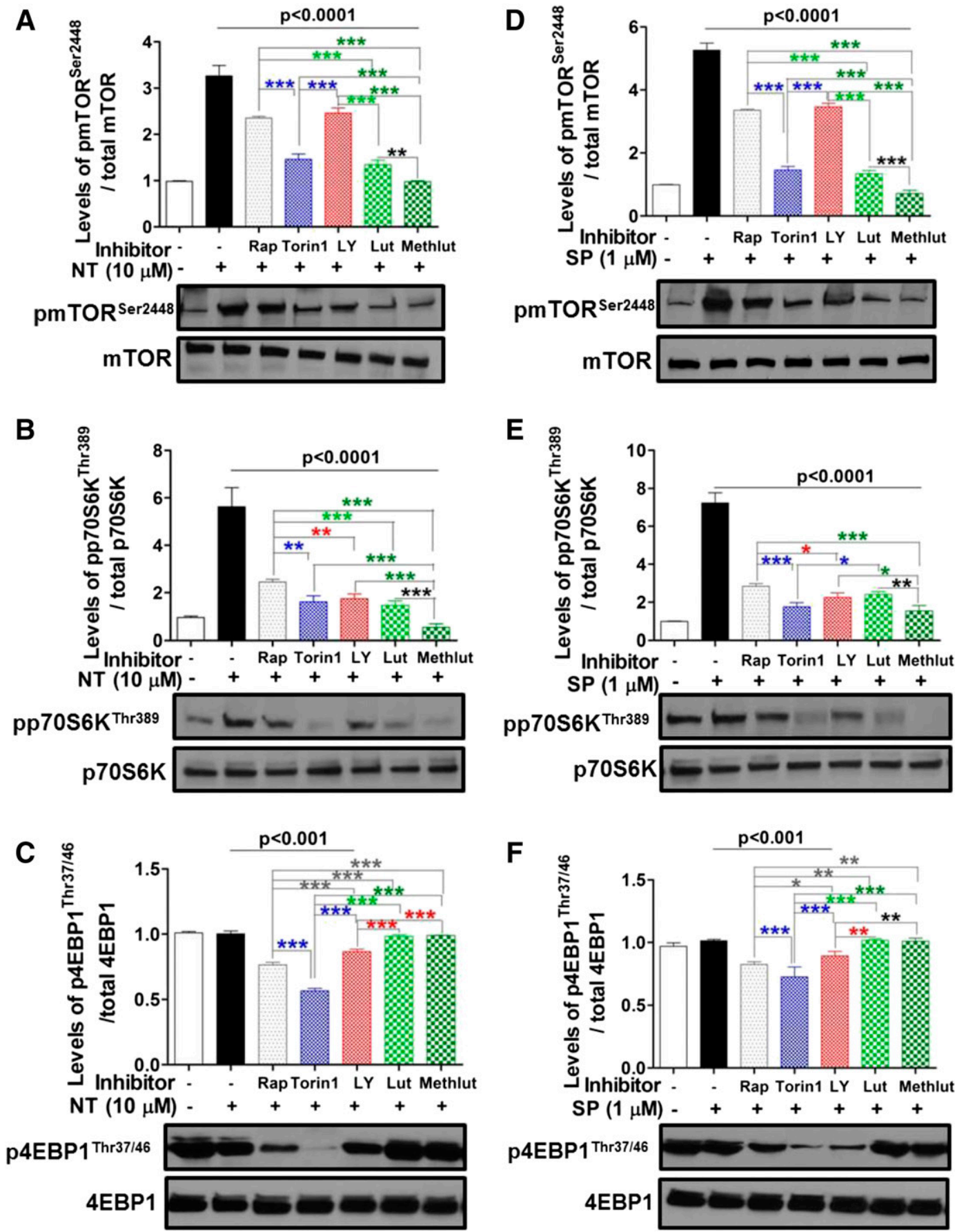

Fig. 5. NT- or SP-stimulated mTOR activation in LAD2 MCs is inhibitable by luteolin and methoxyluteolin. (A-F) LAD 2 MCs $\left(1 \times 10^{6}\right.$ cells) were pretreated with the mTOR inhibitors rapamycin (Rap) and Torin1 $(0.2 \mu \mathrm{M}, 24$ hours), the upstream PI3K inhibitor LY294002 (LY; $10 \mu \mathrm{M}$, 2 hours), or the natural flavonoids luteolin (Lut) and methoxyluteolin (Methlut; 10 or $50 \mu \mathrm{M}, 30$ minutes) prior to stimulation with NT (10 $\mu \mathrm{M})$ (A-C) or SP (1 $\mu \mathrm{M}$ ) (D-F) for 20 minutes to probe for the total and phosphorylated levels of mTOR and substrates p70S6K and 4EBP1 by both phospho-ELISA kits and Western blot analysis (lower image). The protein levels of mTOR and pmTOR Ser2448 (A and D) and the downstream mTORC1 substrates p70S6K and pp70S6K Thr389 (B and E) and 4EBP1 and p4EBP1 Thr37/46 (C and F) were measured using specific total or phospho-ELISA kits for equal amounts of protein lysates, with normalized ratios of phosphorylated to total proteins. All conditions were performed in triplicate for each data set and were repeated three times, with results presented as means \pm S.D. Significance of comparisons was assessed for stimulated cells without any inhibitor (control) and for those with inhibitor/flavonoid, as denoted by the horizontal lines that indicate significance at $P<0.0001$ for each comparison made. All inhibitor/flavonoid treatments were also compared among themselves, and the horizontal brackets indicate the corresponding levels of significance when present $(* P<0.05 ; * * P<0.001 ; * * P<0.0001)$.

VEGF from cultured human MCs in response to stimulation by neuropeptides. Stimulation of LAD2 MCs by either NT or SP markedly increases levels of pmTORSer2448, the mTOR site phosphorylated by upstream PI3K signaling and the
mTORC1-dependent p70S6K Thr389 site, indicating activation of mTOR. In addition, the dual mTORC1 and mTORC2 inhibitor Torin 1 is more potent than the predominant mTORC1 inhibitor rapamycin, suggesting that both complexes may be 
involved in TNF, VEGF, and CXCL8 gene expression in LAD2 MCs. Our results are also in agreement with the previous report that rapamycin blocks FceRI-mediated PI3K-dependent activation of mTORC1 signaling and de novo synthesized interleukin-6 and CXCL8 release from murine MCs (Kim et al., 2008b).

Signaling via mTORC1 was previously implicated in FceRImediated allergic cytokine release (Smrz et al., 2011) and in the regulation of normal MC homeostasis (Kim et al., 2008a). In fact, constitutively activated mTORC1 (Kim et al., 2008a) is critical for the survival of LAD2 MCs (Smrz et al., 2011). Although LAD2 MCs were derived from a patient with MC leukemia (Kirshenbaum et al., 2003), these cells have repeatedly been shown to behave like primary human MCs (Guhl et al., 2010; Zhang et al., 2012a; Weng et al., 2015). One could argue that the findings presented here should be validated in primary human MCs and in some mouse models. However, normal primary MCs derived from the skin were recently shown to have enormous variability in responsiveness (Theoharides et al., 2016) and murine models are now considered to poorly mimic human inflammatory diseases (Seok et al., 2013).

To allow for the de novo synthesis of TNF, CXCL8, and VEGF in human MCs stimulated by either SP or NT, proinflammatory mediator gene expression was measured after 6 hours, whereas mediator protein release was measured after 24 hours to enable protein translation and secretion from MCs. An important new finding reported here is that the flavonoid methoxyluteolin significantly inhibits gene expression and release of all of the proinflammatory mediators, as well as activation of mTOR. Moreover, methoxyluteolin is more potent than luteolin, rapamycin, or Torin1. These findings suggest that mTOR signaling is involved in the transcriptional regulation of mediator induction in human LAD2 MCs in response to stimulation by NT and SP. Luteolin was previously shown to inhibit nuclear factor- $\kappa \mathrm{B}(\mathrm{NF}-\kappa \mathrm{B})-$ mediated proinflammatory TNF synthesis in murine macrophages (Xagorari et al., 2001), whereas our laboratory previously showed that methoxyluteolin inhibits SP-stimulated TNF release from LAD2 MCs and induction of NF- $\kappa \mathrm{B}$ (Weng et al., 2015). Hence, we speculate that methoxyluteolin could target inhibition of PI3K/mTOR signaling that is upstream of NF- $\kappa \mathrm{B}$ (Dan et al., 2008) and/or the signal transducer and activator of transcription (Laplante and Sabatini, 2013; Saleiro and Platanias, 2015) and could, in effect, inhibit these critical transcriptional regulators of proinflammatory cytokines and chemokines (Weichhart et al., 2008). In fact, PI3K/mTOR, $\mathrm{NF}-\kappa \mathrm{B}$, and the signal transducer and activator of transcription have all been implicated in FceRI-mediated allergic activation of human MCs (Kim et al., 2008b; Blatt et al., 2012; Siegel et al., 2013), whereas rapamycin was previously shown to inhibit TNF gene expression in rat MCs (Park et al., 2012).

Unlike the mTOR inhibitors, luteolin and methoxyluteolin also inhibited MC degranulation. This inhibition is even better than that of the PI3K inhibitor LY294002, which is known to be involved in the regulation of MC degranulation (Takayama et al., 2013). Instead, the preferential mTORC1 inhibitor rapamycin and the dual mTORC1/mTORC2 inhibitor Torin 1 did not inhibit NT- or SP-stimulated human MC degranulation, which is in agreement with a recent report showing that FceRI-mediated allergic MC degranulation is regulated by the rictor protein alone, and not via intact
mTORC2 signaling (Smrz et al., 2014). Our findings suggest that the flavonoids luteolin and methoxyluteolin could target inhibition of MC degranulation in an mTOR-independent manner. One such mechanism could involve inhibition of intracellular calcium levels in human MCs, which is required for activation of PI3K and other signaling proteins such as phospholipase C (Gilfillan and Rivera, 2009) and contributes to the regulation of granule exocytosis (Holowka et al., 2012). We previously showed that methoxyluteolin inhibits intracellular calcium levels in human MCs (Weng et al., 2015). In addition, the flavonoids could target specific proteins involved in vesicle fusion, such as soluble $N$-ethylmaleimide-sensitive factor attachment proteins (Yang et al., 2015), implicated in MC degranulation.

Patients with systemic mastocytosis (Metcalfe and Akin, 2001; Theoharides et al., 2015) have increased mTOR gene expression in bone marrow mononuclear cells (Smrz et al., 2011), and it has been suggested that selectively targeting mTOR complexes could effectively reduce proliferation of MCs associated with inflammation and MC disorders. Rapamycin was previously reported to inhibit the survival of Proto-Oncogene Receptor Tyrosine Kinase KIT D816V mutated MCs in culture (Gabillot-Carré et al., 2006), a mutation characteristic in almost $80 \%$ of patients with systemic mastocytosis, rendering the encoded tyrosine kinase receptor and mTOR constitutively active. However, treatment using everolimus, an oral mTOR inhibitor, resulted in toxicity and side effects in patients with systemic mastocytosis (Parikh et al., 2010). More recently, dual inhibitors of PI3K/mTOR that inhibit activation of neoplastic human MCs (Blatt et al., 2012) have been proposed as a treatment for systemic mastocytosis but could have poor tolerability. In addition to treating mastocytosis (Metcalfe and Akin, 2001; Theoharides et al., 2015), methoxyluteolin could also be used for asthma (Galli and Tsai, 2012), atopic dermatitis, (Vasiadi M et al., 2012), and psoriasis (Theoharides et al., 2012a).

Our findings of neuroimmunoendocrine interactions involving the neuropeptides NT and SP and activation of MCs could be important in the pathology of skin disorders (Caraffa et al., 2016). For instance, activation of human MCs via FceRI upregulates the surface expression of the SP neurokinin receptors (Kulka et al., 2008). We previously showed that SP (Asadi et al., 2012) and NT (Alysandratos et al., 2012) induce the expression of corticotropin-releasing hormone receptor 1 in human MCs, through which NT synergistically with corticotropin-releasing hormone stimulates VEGF release (Donelan et al., 2006) and MC degranulation (Pang et al., 1998). LAD2 MCs express NT receptor 1 (Alysandratos et al., 2012), whereas other human MC lines also synthesize precursor NT peptides (Cochrane et al., 2011). MCs can also degrade NT (Piliponsky et al., 2008), indicating tight regulation. Moreover, SP induces adhesion molecules on endothelial cells, resulting in infiltration of other immune cells such as neutrophils and eosinophils (Quinlan et al., 1999). Hence, the elevated circulating levels of SP and/or NT in patients with psoriasis and atopic dermatitis (Vasiadi M et al., 2012) could have relevance in pathophysiologic settings. Furthermore, we recently reported increased levels of TNF, SP, and the SP structural analog hemokinin A in patients with fibromyalgia (Tsilioni et al., 2016). Interestingly, hemokinin A was reported to be secreted from rodent MCs and to have an autocrine action on MCs (Sumpter et al., 2015). 
The ability of NT to stimulate mTOR activation in MCs reported here is additionally intriguing, given the increased levels of NT in patients with autism spectrum disorders (ASDs) (Angelidou et al., 2010; Tsilioni et al., 2014) who also have skin allergies (Theoharides et al., 2016). Communication between MCs and microglia has been invoked in brain inflammation brain (Skaper et al., 2014), and increasing evidence indicates that MCs and brain inflammation (Esposito et al., 2002) are involved in the pathogenesis of ASD (Theoharides et al., 2016). Microglia, the resident immune cells of the brain, are stimulated by MC-derived histamine (Dong et al., 2014) and tryptase (Zhang et al., 2012b). Moreover, about $1 \%-5 \%$ of ASD cases have gene mutations in regulatory proteins upstream of mTOR (Willsey and State, 2015), removing any innate inhibition of this signaling complex. We recently showed that NT can stimulate cultured human microglia, an action inhibited by methoxyluteolin (Patel et al., 2016).

Our findings of mTOR activation in neuropeptide-stimulated MCs and its inhibition by methoxyluteolin have clear therapeutic potential. In fact, two open-label clinical studies reported that a luteolin-containing dietary formulation significantly improved attention and sociability in children with ASD (Theoharides et al., 2012b; Taliou et al., 2013), while a combination of luteolin with palmitoylethanolamide was further reported to have significant benefit in cerebral ischemia in humans (Caltagirone et al., 2016). Therapeutically, methoxyluteolin could be superior to luteolin for treating patients with MC disorders not only because it is a more potent inhibitor of MC and mTOR activation, but its four additional methyl groups, compared with luteolin, increase its solubility, absorption, and metabolic stability (Walle, 2007). Moreover, since flavonoids typically have low oral bioavailability of less than $10 \%$ in humans (Williamson and Manach, 2005), utilizing novel drug delivery systems (e.g., encapsulation of methoxyluteolin into liposomes coated with a targeting ligand) could improve bioavailability and enhance delivery to sites of inflammation where activated MCs are present.

\section{Acknowledgments}

The authors thank Dr. A. S. Kirshenbaum (National Institutes of Health) for providing LAD2 human MCs. They also thank Swedish Orphan Biovitrum for the generous gift of recombinant human stem cell factor. Finally, the authors thank Drs. William Bachovchin, David Sanford, and Yuhong Zhou (Tufts University School of Medicine) for checking the purity of methoxyluteolin using nuclear magnetic resonance and mass spectroscopy, as well as Dr. Chia-Ling Tsai (Kainan University, Taoyuan City, Taiwan) for providing a chemically synthesized methoxyluteolin standard.

\section{Authorship Contributions}

Participated in research design: Patel, Theoharides.

Conducted experiments: Patel.

Performed data analysis: Patel.

Wrote or contributed to the writing of the manuscript: Patel, Theoharides.

\section{References}

Alysandratos KD, Asadi S, Angelidou A, Zhang B, Sismanopoulos N, Yang H, Critchfield A, and Theoharides TC (2012) Neurotensin and CRH interactions augment human mast cell activation. PLoS One 7:e48934.

Angelidou A, Francis K, Vasiadi M, Alysandratos K-D, Zhang B, Theoharides A, Lykouras L, Sideri K, Kalogeromitros D, and Theoharides TC (2010) Neurotensin is increased in serum of young children with autistic disorder. $J$ Neuroinflammation 7:48.

Asadi S, Alysandratos KD, Angelidou A, Miniati A, Sismanopoulos N, Vasiadi M, Zhang B, Kalogeromitros D, and Theoharides TC (2012) Substance P (SP) induces expression of functional corticotropin-releasing hormone receptor-1 (CRHR-1) in human mast cells. J Invest Dermatol 132:324-329.

Beck LA (2005) The efficacy and safety of tacrolimus ointment: a clinical review. $J$ Am Acad Dermatol 53 (Suppl 2):S165-S170.

Blatt K, Herrmann H, Mirkina I, Hadzijusufovic E, Peter B, Strommer S, Hoermann G, Mayerhofer M, Hoetzenecker K, Klepetko W, et al. (2012) The PI3-kinase/mTORtargeting drug NVP-BEZ235 inhibits growth and IgE-dependent activation of human mast cells and basophils. PLoS One 7:e29925.

Caltagirone C, Cisari C, Schievano C, Di Paola R, Cordaro M, Bruschetta G, Esposito E, and Cuzzocrea S; Stroke Study Group (2016) Co-ultramicronized palmitoylethanolamide/luteolin in the treatment of cerebral ischemia: from rodent to man. Transl Stroke Res 7:54-69.

Caraffa A, Spinas E, Kritas SK, Lessiani G, Ronconi G, Saggini A, Antinolfi P, Pizzicannella J, Toniato E, Theoharides TC, et al. (2016) Endocrinology of the skin: intradermal neuroimmune network, a new frontier. J Biol Regul Homeost Agents 30:339-343.

Carraway R and Leeman SE (1973) The isolation of a new hypotensive peptide, neurotensin, from bovine hypothalami. J Biol Chem 248:6854-6861.

Chang MM and Leeman SE (1970) Isolation of a sialogogic peptide from bovine hypothalamic tissue and its characterization as substance P. J Biol Chem 245: $4784-4790$.

Church MK, el-Lati S, and Caulfield JP (1991) Neuropeptide-induced secretion from human skin mast cells. Int Arch Allergy Appl Immunol 94:310-318.

Cochrane DE, Carraway RE, Harrington K, Laudano M, Rawlings S, and Feldberg RS (2011) HMC-1 human mast cells synthesize neurotensin (NT) precursor, secrete bioactive NT-like peptide(s) and express NT receptor NTS1. Inflamm Res 60:1139-1151.

Dan HC, Cooper MJ, Cogswell PC, Duncan JA, Ting JP, and Baldwin AS (2008) Aktdependent regulation of NF-kappaB is controlled by mTOR and Raptor in association with IKK. Genes Dev 22:1490-1500.

Dibble CC and Cantley LC (2015) Regulation of mTORC1 by PI3K signaling. Trends Cell Biol 25:545-555.

Donelan J, Boucher W, Papadopoulou N, Lytinas M, Papaliodis D, Dobner P, and Theoharides TC (2006) Corticotropin-releasing hormone induces skin vascular permeability through a neurotensin-dependent process. Proc Natl Acad Sci USA 103:7759-7764.

Dong H, Zhang W, Zeng X, Hu G, Zhang H, He S, and Zhang S (2014) Histamine induces upregulated expression of histamine receptors and increases release of inflammatory mediators from microglia. Mol Neurobiol 49:1487-1500.

Esposito P, Chandler N, Kandere K, Basu S, Jacobson S, Connolly R, Tutor D, and Theoharides TC (2002) Corticotropin-releasing hormone and brain mast cells regulate blood-brain-barrier permeability induced by acute stress. $J$ Pharmacol Exp Ther 303:1061-1066

Finn DF and Walsh JJ (2013) Twenty-first century mast cell stabilizers. $B r J$ Pharmacol 170:23-37.

Furumoto Y, Brooks S, Olivera A, Takagi Y, Miyagishi M, Taira K, Casellas R, Beaven MA, Gilfillan AM, and Rivera J (2006) Cutting edge: lentiviral short hairpin RNA silencing of PTEN in human mast cells reveals constitutive signals that promote cytokine secretion and cell survival. $J$ Immunol 176:5167-5171.

Furumoto Y, Charles N, Olivera A, Leung WH, Dillahunt S, Sargent JL, Tinsley K, Odom S, Scott E, Wilson TM, et al. (2011) PTEN deficiency in mast cells causes a mastocytosis-like proliferative disease that heightens allergic responses and vascular permeability. Blood 118:5466-5475.

Gabillot-Carré M, Lepelletier Y, Humbert M, de Sepuvelda P, Hamouda NB, Zappulla JP, Liblau R, Ribadeau-Dumas A, Machavoine F, Letard S, et al. (2006) Rapamycin inhibits growth and survival of D816V-mutated c-kit mast cells. Blood 108:1065-1072.

Galli SJ, Grimbaldeston M, and Tsai M (2008) Immunomodulatory mast cells: negative, as well as positive, regulators of immunity. Nat Rev Immunol 8:478-486.

Galli SJ and Tsai M (2012) IgE and mast cells in allergic disease. Nat Med 18: 693-704.

Gilfillan AM and Rivera J (2009) The tyrosine kinase network regulating mast cell activation. Immunol Rev 228:149-169.

Gotlib J, Kluin-Nelemans HC, George TI, Akin C, Sotlar K, Hermine O, Awan FT, Hexner E, Mauro MJ, Sternberg DW, et al. (2016) Efficacy and safety of midostaurin in advanced systemic mastocytosis. $N$ Engl $J$ Med 374:2530-2541.

Guhl S, Babina M, Neou A, Zuberbier T, and Artuc M (2010) Mast cell lines HMC-1 and LAD2 in comparison with mature human skin mast cells-drastically reduced levels of tryptase and chymase in mast cell lines. Exp Dermatol 19:845-847.

Heinrich MC, Griffith DJ, Druker BJ, Wait CL, Ott KA, and Zigler AJ (2000) Inhibition of c-kit receptor tyrosine kinase activity by STI 571, a selective tyrosine kinase inhibitor. Blood 96:925-932.

Holowka D, Calloway N, Cohen R, Gadi D, Lee J, Smith NL, and Baird B (2012) Roles for ca $(2+)$ mobilization and its regulation in mast cell functions. Front Immunol 3 104 .

Kempuraj D, Madhappan B, Christodoulou S, Boucher W, Cao J, Papadopoulou N, Cetrulo CL, and Theoharides TC (2005) Flavonols inhibit proinflammatory mediator release, intracellular calcium ion levels and protein kinase $\mathrm{C}$ theta phosphorylation in human mast cells. Br J Pharmacol 145:934-944.

Kim MS, Kuehn HS, Metcalfe DD, and Gilfillan AM (2008a) Activation and function of the mTORC1 pathway in mast cells. J Immunol 180:4586-4595.

Kim MS, Rådinger M, and Gilfillan AM (2008b) The multiple roles of phosphoinositide 3-kinase in mast cell biology. Trends Immunol 29:493-501.

Kimata M, Shichijo M, Miura T, Serizawa I, Inagaki N, and Nagai H (2000) Effects of luteolin, quercetin and baicalein on immunoglobulin E-mediated mediator release from human cultured mast cells. Clin Exp Allergy 30:501-508.

Kirshenbaum AS, Akin C, Wu Y, Rottem M, Goff JP, Beaven MA, Rao VK, and Metcalfe DD (2003) Characterization of novel stem cell factor responsive human mast cell lines LAD 1 and 2 established from a patient with mast cell sarcoma/leukemia; activation following aggregation of FcepsilonRI or FcgammaRI. Leuk Res 27:677-682. 
Kitamura Y and Ito A (2005) Mast cell-committed progenitors. Proc Natl Acad Sci USA 102:11129-11130.

Kuehn HS, Jung MY, Beaven MA, Metcalfe DD, and Gilfillan AM (2011) Prostaglandin E2 activates and utilizes mTORC2 as a central signaling locus for the regulation of mast cell chemotaxis and mediator release. J Biol Chem 286:391-402.

Kulka M, Sheen CH, Tancowny BP, Grammer LC, and Schleimer RP (2008) Neuropeptides activate human mast cell degranulation and chemokine production. Immunology 123:398-410.

Laplante M and Sabatini DM (2012) mTOR signaling in growth control and disease. Cell 149:274-293.

Laplante M and Sabatini DM (2013) Regulation of mTORC1 and its impact on gene expression at a glance. J Cell Sci 126:1713-1719.

Lazarus LH, Perrin MH, and Brown MR (1977) Mast cell binding of neurotensin. I. Iodination of neurotensin and characterization of the interaction of neurotensin with mast cell receptor sites. J Biol Chem 252:7174-7179.

Mashaghi A, Marmalidou A, Tehrani M, Grace PM, Pothoulakis C, and Dana R (2016) Neuropeptide substance P and the immune response. Cell Mol Life Sci 73: $4249-4264$.

McNeil BD, Pundir P, Meeker S, Han L, Undem BJ, Kulka M, and Dong X (2015) Identification of a mast-cell-specific receptor crucial for pseudo-allergic drug reactions. Nature 519:237-241.

Metcalfe DD and Akin C (2001) Mastocytosis: molecular mechanisms and clinical disease heterogeneity. Leuk Res 25:577-582.

Michel G, Kemeny L, Homey B, and Ruzicka T (1996) FK506 in the treatment of inflammatory skin disease: promises and perspectives. Immunol Today 17:106-108.

Middleton E, Jr, Kandaswami C, and Theoharides TC (2000) The effects of plant flavonoids on mammalian cells: implications for inflammation, heart disease, and cancer. Pharmacol Rev 52:673-751.

Mlcek J, Jurikova T, Skrovankova S, and Sochor J (2016) Quercetin and its antiallergic immune response. Molecules 21:E623.

O'Connor TM, O'Connell J, O'Brien DI, Goode T, Bredin CP, and Shanahan F (2004) The role of substance P in inflammatory disease. J Cell Physiol 201:167-180.

Oka T, Kalesnikoff J, Starkl P, Tsai M, and Galli SJ (2012) Evidence questioning cromolyn's effectiveness and selectivity as a 'mast cell stabilizer' in mice. Lab Invest 92:1472-1482

Palaska I, Gagari E, and Theoharides TC (2016) The effects of P. gingivalis and E. coli LPS on the expression of proinflammatory mediators in human mast cells and their relevance to periodontal disease. J Biol Regul Homeost Agents 30:655-664.

Pang X, Alexacos N, Letourneau R, Seretakis D, Gao W, Boucher W, Cochrane DE, and Theoharides TC (1998) A neurotensin receptor antagonist inhibits acute immobilization stress-induced cardiac mast cell degranulation, a corticotropin-releasing hormone-dependent process. J Pharmacol Exp Ther 287:307-314.

Parikh SA, Kantarjian HM, Richie MA, Cortes JE, and Verstovsek S (2010) Experience with everolimus (RAD001), an oral mammalian target of rapamycin inhibitor, in patients with systemic mastocytosis. Leuk Lymphoma 51:269-274.

Park JW, Jeon YJ, Lee JC, Ahn SR, Ha SW, Bang SY, Park EK, Yi SA, Lee MG, and Han JW (2012) Destabilization of TNF- $\alpha$ mRNA by rapamycin. Biomol Ther (Seoul) 20:43-49.

Patel AB, Tsilioni I, Leeman SE, and Theoharides TC (2016) Neurotensin stimulates sortilin and mTOR in human microglia inhibitable by methoxyluteolin, a potentia therapeutic target for autism. Proc Natl Acad Sci U S A 113:E7049-E7058.

Piliponsky AM, Chen CC, Nishimura T, Metz M, Rios EJ, Dobner PR, Wada E, Wada K, Zacharias S, Mohanasundaram UM, et al. (2008) Neurotensin increases mortality and mast cells reduce neurotensin levels in a mouse model of sepsis. Nat Med 14:392-398.

Quinlan KL, Song IS, Naik SM, Letran EL, Olerud JE, Bunnett NW, Armstrong CA, Caughman SW, and Ansel JC (1999) VCAM-1 expression on human dermal microvascular endothelial cells is directly and specifically up-regulated by substance P. J Immunol 162:1656-1661.

Remröd C, Lonne-Rahm S, and Nordlind K (2007) Study of substance P and its receptor neurokinin-1 in psoriasis and their relation to chronic stress and pruritus. Arch Dermatol Res 299:85-91.

Rivera J, Fierro NA, Olivera A, and Suzuki R (2008) New insights on mast cell activation via the high affinity receptor for IgE. Adv Immunol 98:85-120.

Rodewald HR, Dessing M, Dvorak AM, and Galli SJ (1996) Identification of a committed precursor for the mast cell lineage. Science 271:818-822.

Salamon P, Shoham NG, Gavrieli R, Wolach B, and Mekori YA (2005) Human mast cells release interleukin- 8 and induce neutrophil chemotaxis on contact with activated T cells. Allergy 60:1316-1319.

Saleiro D and Platanias LC (2015) Intersection of mTOR and STAT signaling in immunity. Trends Immunol 36:21-29.

Schmetzer O, Valentin P, Church MK, Maurer M, and Siebenhaar F (2016) Murine and human mast cell progenitors. Eur J Pharmacol 778:2-10

Seok J, Warren HS, Cuenca AG, Mindrinos MN, Baker HV, Xu W, Richards DR, McDonald-Smith GP, Gao H, Hennessy L, et al.; Inflammation and Host Response to Injury, Large Scale Collaborative Research Program (2013) Genomic responses in mouse models poorly mimic human inflammatory diseases. Proc Natl Acad Sci USA 110:3507-3512.

Siegel AM, Stone KD, Cruse G, Lawrence MG, Olivera A, Jung MY, Barber JS, Freeman AF, Holland SM, O'Brien M, et al. (2013) Diminished allergic disease in patients with STAT3 mutations reveals a role for STAT3 signaling in mast cell degranulation. J Allergy Clin Immunol 132:1388-1396.

Skaper SD, Facci L, and Giusti P (2014) Mast cells, glia and neuroinflammation: partners in crime? Immunology 141:314-327.
Smrz D, Cruse G, Beaven MA, Kirshenbaum A, Metcalfe DD, and Gilfillan AM (2014) Rictor negatively regulates high-affinity receptors for IgE-induced mast cell degranulation. J Immunol 193:5924-5932.

Smrz D, Kim MS, Zhang S, Mock BA, Smrzová S, DuBois W, Simakova O, Maric I, Wilson TM, Metcalfe DD, et al. (2011) mTORC1 and mTORC2 differentially regulate homeostasis of neoplastic and non-neoplastic human mast cells. Blood 118:6803-6813.

Sumpter TL, Ho $\mathrm{CH}$, Pleet AR, Tkacheva OA, Shufesky WJ, Rojas-Canales DM, Morelli AE, and Larregina AT (2015) Autocrine hemokinin-1 functions as an endogenous adjuvant for IgE-mediated mast cell inflammatory responses. J Allergy Clin Immunol 135:1019-30.e8.

Takayama G, Ohtani M, Minowa A, Matsuda S, and Koyasu S (2013) Class I PI3Kmediated Akt and ERK signals play a critical role in FceRI-induced degranulation in mast cells. Int Immunol 25:215-220.

Taliou A, Zintzaras E, Lykouras L, and Francis K (2013) An open-label pilot study of a formulation containing the anti-inflammatory flavonoid luteolin and its effects on behavior in children with autism spectrum disorders. Clin Ther 35:592-602.

Theoharides TC, Alysandratos KD, Angelidou A, Delivanis DA, Sismanopoulos N, Zhang B, Asadi S, Vasiadi M, Weng Z, Miniati A, et al. (2012a) Mast cells and inflammation. Biochim Biophys Acta 1822:21-33.

Theoharides TC, Asadi S, and Panagiotidou S (2012b) A case series of a luteolin formulation (NeuroProtek ${ }^{\circledR}$ ) in children with autism spectrum disorders. Int $J$ Immunopathol Pharmacol 25:317-323.

Theoharides TC and Cochrane DE (2004) Critical role of mast cells in inflammatory diseases and the effect of acute stress. $J$ Neuroimmunol 146:1-12.

Theoharides TC, Sieghart W, Greengard P, and Douglas WW (1980) Antiallergic drug cromolyn may inhibit histamine secretion by regulating phosphorylation of a mast cell protein. Science 207:80-82.

Theoharides TC, Tsilioni I, Patel AB, and Doyle R (2016) Atopic diseases and inflammation of the brain in the pathogenesis of autism spectrum disorders. Transl Psychiatry 6:e844.

Theoharides TC, Valent P, and Akin C (2015) Mast cells, mastocytosis, and related disorders. N Engl J Med 373:163-172.

Theoharides TC, Zhang B, Kempuraj D, Tagen M, Vasiadi M, Angelidou A, Alysandratos KD, Kalogeromitros D, Asadi S, Stavrianeas N, et al. (2010) IL-33 augments substance $\mathrm{P}$-induced VEGF secretion from human mast cells and is increased in psoriatic skin. Proc Natl Acad Sci USA 107:4448-4453.

Tsilioni I, Dodman N, Petra AI, Taliou A, Francis K, Moon-Fanelli A, Shuster L, and Theoharides TC (2014) Elevated serum neurotensin and CRH levels in children with autistic spectrum disorders and tail-chasing Bull Terriers with a phenotype similar to autism. Transl Psychiatry 4:e466.

Tsilioni I, Russell IJ, Stewart JM, Gleason RM, and Theoharides TC (2016) Neuropeptides CRH, SP, HK-1, and inflammatory cytokines IL-6 and TNF are increased in serum of patients with fibromyalgia syndrome, implicating mast cells. J Pharmacol Exp Ther 356:664-672.

Vasiadi M, Therianou A, Sideri K, Smyrnioti M, Sismanopoulos N, Delivanis DA Asadi S, Katsarou-Katsari A, Petrakopoulou T, Theoharides A, et al. (2012) Increased serum CRH levels with decreased skin CRHR-1 gene expression in psoriasis and atopic dermatitis. J Allergy Clin Immunol 129:1410-1413.

Vieira Dos Santos R, Magerl M, Martus P, Zuberbier T, Church MK, Escribano L, and Maurer M (2010) Topical sodium cromoglicate relieves allergen- and histamine-induced dermal pruritus. $\mathrm{Br} J$ Dermatol 162:674-676.

Walle T (2007) Methylation of dietary flavones greatly improves their hepatic metabolic stability and intestinal absorption. Mol Pharm 4:826-832.

Weichhart T, Costantino G, Poglitsch M, Rosner M, Zeyda M, Stuhlmeier KM, Kolbe T, Stulnig TM, Hörl WH, Hengstschläger M, et al. (2008) The TSC-mTOR signaling pathway regulates the innate inflammatory response. Immunity 29:565-577.

Weng Z, Patel AB, Panagiotidou S, and Theoharides TC (2015) The novel flavone tetramethoxyluteolin is a potent inhibitor of human mast cells. J Allergy Clin Immunol 135:1044-52.e5.

Weng Z, Zhang B, Asadi S, Sismanopoulos N, Butcher A, Fu X, Katsarou-Katsari A Antoniou C, and Theoharides T (2012) Quercetin is more effective than cromolyn in blocking human mast cell cytokine release and inhibits contact dermatitis and photosensitivity in humans. PLoS One 7:e33805.

Williamson G and Manach C (2005) Bioavailability and bioefficacy of polyphenols in humans. II. Review of 93 intervention studies. Am J Clin Nutr 81 (Suppl):243S-255S.

Willsey AJ and State MW (2015) Autism spectrum disorders: from genes to neurobiology. Curr Opin Neurobiol 30:92-99.

Xagorari A, Papapetropoulos A, Mauromatis A, Economou M, Fotsis T, and Roussos C (2001) Luteolin inhibits an endotoxin-stimulated phosphorylation cascade and proinflammatory cytokine production in macrophages. J Pharmacol Exp Ther 296:181-187.

Yang Y, Heo P, Kong B, Park JB, Jung YH, Shin J, Jeong C, and Kweon DH (2015) Dynamic light scattering analysis of SNARE-driven membrane fusion and the ef fects of SNARE-binding flavonoids. Biochem Biophys Res Commun 465:864-870.

Zhang B, Asadi S, Weng Z, Sismanopoulos N, and Theoharides TC (2012a) Stimulated human mast cells secrete mitochondrial components that have autocrine and paracrine inflammatory actions. PLoS One 7:e49767.

Zhang S, Zeng X, Yang H, Hu G, and He S (2012b) Mast cell tryptase induces microglia activation via protease-activated receptor 2 signaling. Cell Physiol Biochem 29:931-940.

Address correspondence to: Dr. Theoharis C. Theoharides, Department of Integrative Physiology and Pathobiology, Tufts University School of Medicine, 136 Harrison Avenue, Suite J 304, Boston, MA 02111. E-mail: theoharis. theoharides@tufts.edu 